\title{
Design of Mathematics Student Worksheet based on Discovery Learning Approach to Improving Mathematical Representation Ability Students of Grade VII Junior High School in Indonesia
}

\author{
Eka Luthfiana Lathifah ${ }^{1 *}$, Suparman ${ }^{2}$ \\ ${ }^{1,2}$ Master of Mathematics Education, University of Ahmad Dahlan, Indonesia \\ *Corresponding author E-mail: luthfianaeka@gmail.com
}

\begin{abstract}
The ability of mathematical representation is very important for someone to help in solving the problem. This type of research is a development research. This article aims to obtain a student workbook design based on Discovery Learning that is oriented towards students' mathematical representation abilities. This research is a research development of Research and Development (R \& D) with 4D development model which includes defining, design, development, and dissemination. This study is limited only to the design stage. Subjects in this study are students of junior high school grade VII in central java Indonesia. An instrument used in this study in the form of essay questions, questionnaire and interview guidelines. This research resulted in the worksheet (LKS) design based on Discovery Learning based on the ability of mathematical representation to improve the ability of mathematical representation. The next stage will be the research stage of development and dissemination to produce a valid, practical, and useful worksheet.
\end{abstract}

Keywords: Discovery Learning, Mathematics Representation, Worksheet.

\section{Introduction}

One of the main subjects to be taught to students in mathematics. Most students consider that mathematics is complicated, so students become lazy to understand mathematic [1]. Based on research conducted by Gustavo and Merisa in Mexico shows most students stated that mathematics and life are closely related, which means that mathematic is very useful for the life of the world[2]. The standard of mathematical ability that must be possessed by students is problem-solving ability, communication ability, connection ability, reasoning ability, and the ability of representation[3].

Representation is an expression of students' mathematical ideas or ideas in their search for solutions to the problems they are facing. Mathematical representation is an option to express and describe mathematical ideas/concepts [4]. Lessons that pay attention to mathematical representation tend to produce more successful mathematical learning [5]. Using visual representation can help in understanding the problem and can improve students' mathematical reasoning abilities [6].

The correct use of mathematical representations and connections will make the accurate notion that is being learned more concretely and can connect between concepts, to view mathematics as a complete integration [7]. Student representation influences their way of forming generalizations and justifying what has been done [8]. The ability to represent something is not easy, one of which is to describe the visual form in the form of a graph [9]. Representation is one of the capabilities students must master to compete in the global world, as can be seen in the picture below [10].

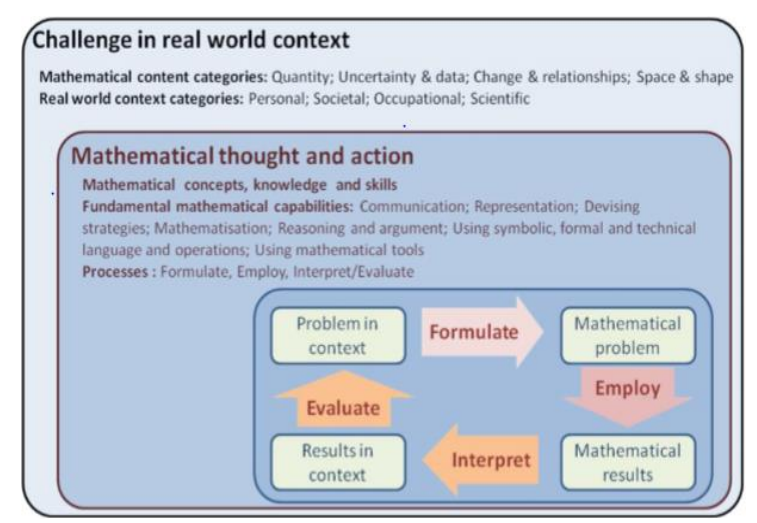

Fig. 1: Challenge in real world context

In Programme for International Students Assesments (PISA) in 2015 shows that Indonesia is still ranked in the bottom 10 [10]. One of the contexts tested in the PISA problem is the ability of representation, meaning that the ability of student representation in Indonesia is still low. The results of other studies indicate the ability of mathematical representation of prospective teachers is still relatively low [7]. Student performance and student representation test at one of the junior high schools in North Sumatra fall into the low category [11]. In line with the results of PISA and some of these studies, researchers have conducted research conducted in MTs Ngalian, Wonosobo Indonesia also showed that students' mathematical representation ability is still very low. This can be known from the answers of students who are mostly wrong because students are not able to represent the given problem.

The 2013 curriculum expects student learning to have skills, attitudes of competence and knowledge through a scientific approach. 
The results of Ovie and Rita showed that the Guided Discovery Model could improve students' representation and activity capability [12]. Besides, the model with the other scientific approach is the Discovery Learning model. Discovery Learning method can improve student representation ability [13]. One of the models that can improve student achievement significantly is the Discovery Learning model [14]. Model Discovery Learning is a model of learning that can make students construct knowledge of students themselves [15]. Discovery Learning helps students to find concepts and ideas in learning [16]. Based on the knowledge and experience that students have been able to explore in understanding the concept [17] within reach of deep learning (explorative)[17] Student learning activities are the basis of this model, where students actively find their information and teachers only as facilitators. The main purpose of learning by using the model of Discovery Learning is to increase students' confidence in finding and developing the mind [18] [19]. Besides, students are also encouraged to improve mastery, comprehension, and explanation of general skills [20].

In implementing the Discovery Learning model required a device, teaching materials, media, and learning instrument results. From some research results above the development of teaching materials should be done based on students' difficulties in the ability of mathematical representation [7]. The use of teaching materials helps students to adjust to the speed of learning and able to learn individually [21].

The Discovery Learning model-based module is effective in improving generic science skills [22]. In addition to modules, one of the teaching materials that are often used in schools is the Student Worksheet (LKS). Based on the research, many schools have used LKS in learning, but there is no LKS that based on the model of Discovery Learning and oriented to students' mathematical representation ability. For that researchers will develop LKS mathematics based Discovery Learning model with oriented to the students mathematical representation abilities.

\section{Method}

The type of research conducted is research development. This research develops Student Worksheet (LKS) based on Discovery Learning and oriented to students' mathematical representation ability. The development of LKS is done by using 4D model. The 4D model (Four D) was first developed by S. Thiagarajan, Dorothy S. Semmel, and Melvyn I. Semmel. The 4D model has four stages: the defining, the design, the development, and the dissemination

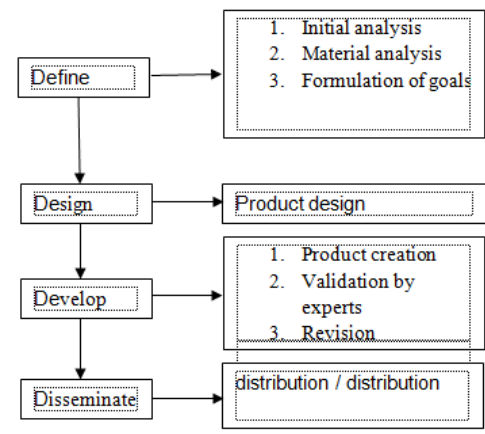

Fig. 2: Flowchart of 4D model

In this article is limited only to the design stage of development of discovery-based student worksheets that are oriented towards students' mathematical representation abilities. Subjects in this study were students of junior high school grade VII in central java Indonesia. The instrument of data collection in this research is by using questionnaire, question sheets, and interview. Methods of data collection conducted tests, questionnaires, and interviews.
Questionnaires are given to students to obtain data on student characteristics. Interviews were conducted with selected teachers and students to strengthen the data collected.

Data analysis technique in this research is by using descriptive analysis technique. The method is done by using descriptive statistic. Data analysis obtained from validation test questionnaire by experts and test of the respondent (student) is done to know the feasibility of student worksheet developed. The scale used in this questionnaire is Likert scale 1-4 with criteria "Very Eligible (SL), Eligible (L), Ineligible (TL), and Very Ineligible (STL)."

The score of each alternative answer on the Likert scale:

Table 1: Likert scale of statement

\begin{tabular}{|c|c|}
\hline \multicolumn{2}{|c|}{ Statement } \\
\hline Alternative Answers & Score \\
\hline Very Eligible (SL) & 4 \\
\hline Eligible (L) & 3 \\
\hline Ineligible (TL) & 2 \\
\hline Very Ineligible (STL) & 1 \\
\hline
\end{tabular}

From the data obtained, then calculate the average of each question by using the formula:

$\bar{x}=\frac{\sum x}{N}$

Information:

$\bar{x}=$ average score

$\sum x=$ total score

$N=$ number of items

Having obtained the average of each question, then convert the data into qualitative data. The conversion criterion score by Djemari Mardapi (2008: 123) is as follows:

Table 2: Criterion score by Djemari Mardapi

\begin{tabular}{|l|l|}
\hline Interval Score & Criteria \\
\hline $\bar{x}>M i+1,5(S D i)$ & Very Eligible (SL) \\
\hline$M i<x<M i+1,5(S D i)$ & Eligible (L) \\
\hline$M i-1,5(S D i)<\bar{x}<M i$ & Ineligible (TL) \\
\hline$x<M i-1,5(S D i)$ & Very Ineligible (STL) \\
\hline
\end{tabular}

Information:

$M i=$ average $=\frac{\text { maximal score }+ \text { minimal score }}{2}$

$S D i=$ Standard deviation $=S=\sqrt{\frac{\sum_{i=1}^{n}\left(x_{i}-\bar{x}\right)^{2}}{n-1}}$

$\bar{x} \quad=$ Average score

\section{Result and Discussion}

This research is a type of Research and development (R \& D) research. This study aims to produce products in the form of LKS development. Development of Student Worksheet (LKS) in this research is done by using Model 4D (Define, Design, Develop, Disseminate). Results of the study in each stage of 4D model are described as follows:

\subsection{Define Stage}

This stage is done with the aim to obtain information related to the products to be developed as well as the issues underlying the importance of developing Student Worksheets (LKS).

\section{a. Initial analysis}

In the initial analysis, the researcher examines the curriculum referenced by the school to be studied. Based on the results of research, in the school's learning refers to the curriculum 2013

b. Student analysis 
Student analysis is conducted to obtain information relating to the character and ability of students as the foundation of LKS development. Based on the research that has been done, the results show that the ability of students to represent mathematic problems still have difficulty

c. Material analysis

One of the materials that need a mathematical representation ability is the One Variable Linear Equation System (PLSV). So in this research is done PLSV material development found in class VII

d. Formulation of goals

The formulation of the objectives referred to in this stage is an indicator of the achievement of competence. The formulation of this indicator is adjusted to the Basic Competency (KD) that has been determined in the curriculum 2013. LKS is created with the aim to facilitate students in understanding the material and can improve students' mathematical representation

\subsection{Design Stage}

The design stage is the design stage of Student Worksheet (LKS) The prepared LKS contains several components, including learning device design, project idea design, a designing method to be used in LKS. There are three main parts in making the LKS is the introduction, the contents, and the cover.

\section{a. Introduction}

In the introductory section contains LKS supporters, information required by students. The components of the introductory chapter in this LKS include

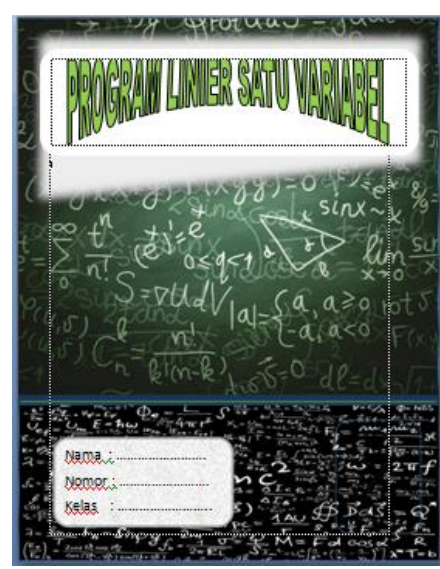

Fig. 3: Cover

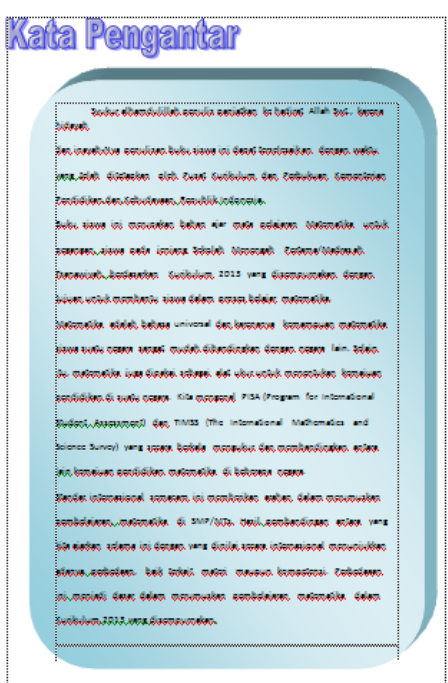

Fig. 4: Foreword
This third picture is the introduction that contains a description or explanation of the created LKS

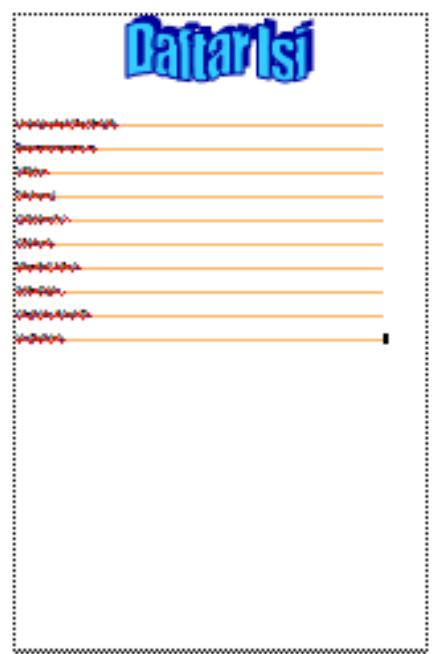

Fig. 4: Table of contents

This fourth picture describes what is contained in the LKS and make it easier for students to find out which part is being searched

\section{b. The Contents}

The content is a core part of the developed LKS. The framework of the materials of the LKS is as follows: Core, Indicator, Learning objectives, Apperception

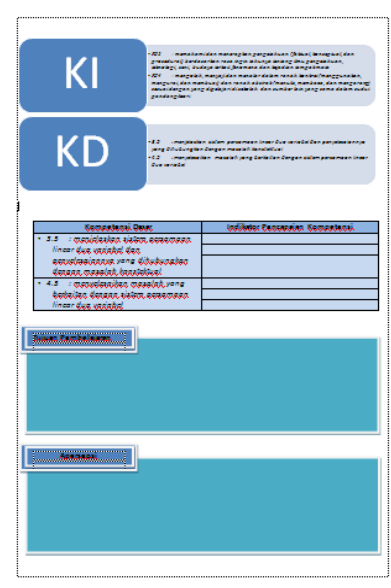

Fig. 5: Basic competencies

These components are written with the intention that learning can be run following the purpose of learning. Besides, to avoid the discussion of material that is off the mark and too broad.

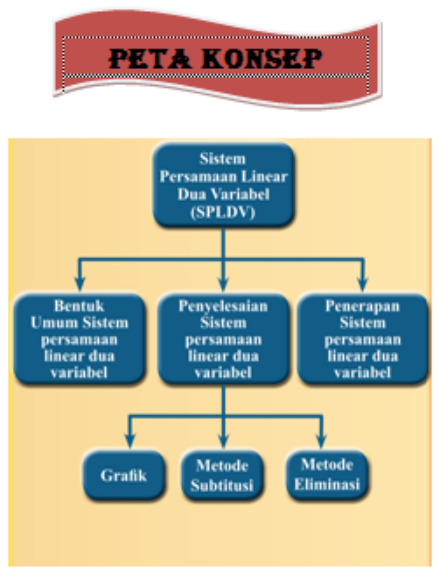




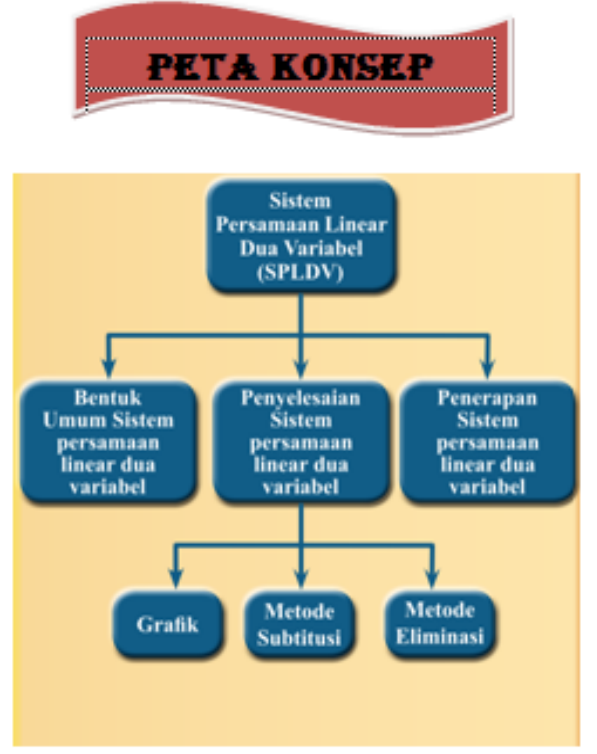

Fig. 6: Concept map

The sixth image is a concept map. This concept map was created with the aim of mapping out what materials will be studied in this LKS.

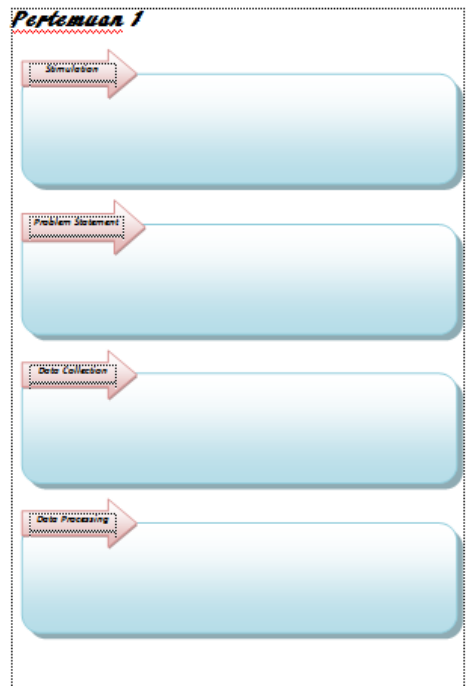

Fig. 7: Materials

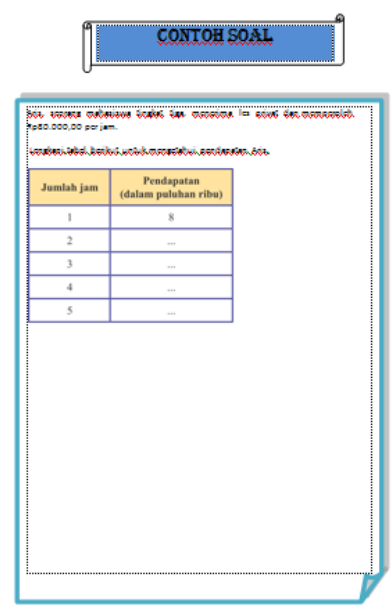

Fig. 8: Questions c. Closing part

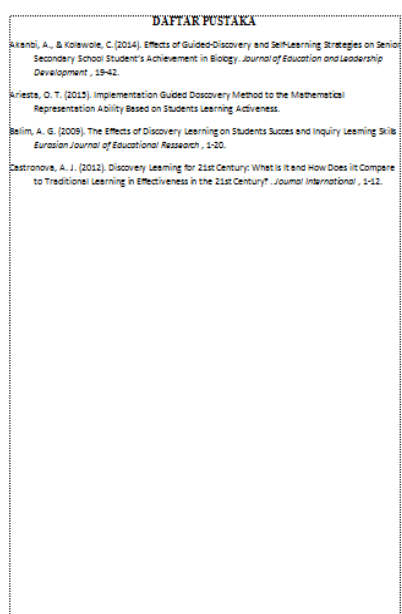

Fig. 9: References

Figure 9 above is a list of libraries that can be used by students as reference materials about the material being studied.

\section{Conclusion}

This research produces student worksheet (LKS) based on Discovery Learning model which is expected to improve students' mathematical representation ability. LKS is divided into three main components, namely the introduction, the contents, and the closing. The introduction consists of cover, introduction, and table of contents. The content consists of core competencies, basic competencies, indicators, objectives, concept maps, apperception, learning materials using Discovery Learning model, sample questions, tasks, practice questions/evaluation. The cover section consists of bibliography and author profile. The development of mathematical representation capability is incorporated into learning materials, sample questions, tasks, and evaluations.

This study is limited only to the design stage. Furthermore, further research will be done on the development of LKS and test the effectiveness of LKS that have been made.

\section{Suggestion}

The design worksheet student Problem-Based Learning is designed to improve mathematics representation abilities of sevengrade high school students. This research can be developed in the development stage and to the field-testing phase to determine the practicality and effectiveness of the student worksheet

\section{References}

[1] Wulandari NW, Nurhanurawati, \& Gunowibowo P (2014), Applying Realistic Mathematical Approach to Improve Students Mathematical Representation (1).

[2] Martinez-Sierra G \& Miranda-Tirado M (2015), Mexican High School Students' Social Representations of Mathematics, its Teaching and Learning. Int. J. Math. Educ. Sci. Technol. 46(5), 700-720.

[3] NCTM, Principles and Standards for School Mathematics. Association Drive Reston, (2000).

[4] Stylianou DA (2010), Teachers' conceptions of representation in middle school mathematics. Journal of Mathematics Teacher Education, 13(4), 325-343

[5] Rau MA \& Matthews PG (2017), How to make 'more' better? Principles for effective use of multiple representations to enhance students' learning about fractions. ZDM 49(4), 531-544.

[6] Debrenti E (2015), Visual Representations in Mathematics Teaching: An Experiment with Students. Acta Didactica Napocensia 8(1) 19-25.

[7] Noto MS, Hartono W \& Sundawan D (2016), Analysis of Students 
Mathematical Representation And Connection On Analytical Geometry Subject. Infinity Journal 5(2), 99-108.

[8] Stylianou DA (2013), An examination of connections in mathematical processes in students' problem solving: Connections between representing and justifying. Journal of Education and Learning, 2(2), 23.

[9] Rahmawati D, Hidayanto E \& Anwar RB (2017), Process of Mathematical Representation Translation from Verbal into Graphic. International Electronic Journal of Mathematics Education 12(3), 367-381.

[10] PISA (2015), Result in Focus https://www.oecd.org/pisa/pisa-2015results-infocus pdf accessed on 27 March 2018 at 21.00 WIB

[11] Minarni A, Napitupulu E \& Husein R (2016), Mathematical understanding and representation ability of public junior high school in north sumatra. Journal on Mathematics Education 7(1), 43-56.

[12] Ariesta OT (2015), Implementation Guided Discovery Method to the Mathematical Representation Ability Based on Student's Learning Activeness.

[13] Muhamad N (2016), Effect of Discovery Learning Method to Improve Students Mathematical Representation and Confidence. $J$. Pendidik. Univ. Garut 9, 9-22.

[14] Suminar SO \& Meilani RI (2016), The Influence of Discovery Learning and Problem Based Learning Models, 1, 84-93.

[15] Chen MJ, Lee CY \& Hsu WC (2015), Influence of mathematical representation and mathematics self-efficacy on the learning effectiveness of fifth graders in pattern reasoning. International Journal of Learning, Teaching and Educational Research 13(1), 1-16.

[16] Kyriazis A, Psycharis S \& Korres K (2009), Discovery learning and the computational experiment in higher mathematics and science education: A combined approach. International Journal of Emerging Technologies in Learning (iJET) 4(4), 25-34.

[17] Balım AG (2009), The Effects of Discovery Learning on Students' Success and Inquiry Learning Skills. Eurasian Journal of Educational Research (EJER) (35), 1-20.

[18] Febriana R, Haryono Y \& Yusri R (2017, September), Effectiveness of Discovery Learning-Based Transformation Geometry Module. In Journal of Physics: Conference Series 895(1), 012003, IOP Publishing.

[19] Ramdhani MR, Usodo B \& Subanti S (2017, September), Discovery Learning with Scientific Approach on Geometry. In Journal of Physics: Conference Series 895(1), 012033, IOP Publishing.

[20] Tompo B, Ahmad A \& Muris M (2016), The Development of Discovery-Inquiry Learning Model to Reduce the Science Misconceptions of Junior High School Students. International Journal of Environmental and Science Education 11(12), 5676-5686.

[21] In'am A \& Hajar S (2017), Learning Geometry through Discovery Learning Using a Scientific Approach. International Journal of Instruction 10(1), 55-70.

[22] Khabibah EN, Masykuri M \& Maridi M (2017), The Effectiveness of Module Based on Discovery Learning to Increase Generic Science Skills. Journal of Education and Learning 11(2), 146-153. 